\title{
Synthesis and Antimicrobial Activity of Carbohydrate Based Schiff Bases: Importance of Sugar Moiety
}

\author{
Helmoz R. Appelt, ${ }^{1}$ Julieta S. Oliveira, ${ }^{2}$ Roberto C. V. Santos, ${ }^{3}$ Oscar E. D. Rodrigues, \\ Maura Z. Santos, ${ }^{3}$ Elisiane F. Heck, ${ }^{3}$ and Líria C. Rosa ${ }^{3}$ \\ ${ }^{1}$ Campus São Gabriel, Universidade Federal do Pampa, Avenida Antônio Trilha 1847, 97300-000 São Gabriel, RS, Brazil \\ ${ }^{2}$ Campus Cerro Largo, Universidade Federal da Fronteira Sul, R. Major Antônio Cardoso 590, 97900-000 Cerro Largo, RS, Brazil \\ ${ }^{3}$ Ciências da Saúde, Centro Universitário Franciscano, Rua dos Andradas 1614-Centro, -97010-032 Santa Maria, RS, Brazil \\ ${ }^{4}$ Departamento de Química, Universidade Federal de Santa Maria, 97105-900 Santa Maria, RS, Brazil
}

Correspondence should be addressed to Helmoz R. Appelt; helmoz@gmail.com

Received 25 September 2013; Revised 12 November 2013; Accepted 14 November 2013

Academic Editor: J. F. Vliegenthart

\begin{abstract}
Copyright ( 2013 Helmoz R. Appelt et al. This is an open access article distributed under the Creative Commons Attribution License, which permits unrestricted use, distribution, and reproduction in any medium, provided the original work is properly cited.
\end{abstract}

A series of D-glucosamine derivatives were synthesized (2-4) and evaluated for their antimicrobial activity. Some of the compounds investigated have shown significant antimicrobial activity against Gram-positive and Gram-negative bacterial strains as well as a few fungal strains. The results suggest that the presence of sugar moiety is necessary to biological activity.

\section{Introduction}

Carbohydrates are the most abundant class of biomolecules, making up $75 \%$ of the biomass on Earth [1]. Carbohydrates are used to store energy but also perform other important functions to life [2].

Recently, carbohydrates and their derivatives have emerged as an important tool for stereoselective synthesis and as a chiral pool for the design of chiral ligands. They are used as chiral building blocks, precursors for drug synthesis and chiral catalysts in asymmetric catalysis [3-8].

Despite the importance of carbohydrates in biological events, the pace of development of carbohydrate based therapeutics has been relatively slow. This is mainly due to practical synthetic and analytical difficulty. Recent advances in the field, however, have demonstrated that many of these problems can be circumvented and evidence the importance of carbohydrates as bioactive substances, with regard to antibacterial, antiviral, antineoplastic, antiprotozoal, and antifungal activity among others, related recently in literature $[9,10]$.
On the other hand, imines or Schiff bases are easily generated by condensation of carbonyl groups and primary amines. In carbohydrate chemistry, a large number of imines have been reported, both by reaction of sugar aldehydes with amines and by reaction of aminosugars with aldehydes [11-16]. Schiff bases and their metal complexes have several applications as catalysts in oxygenations, hydrolysis, and other reactions, antimicrobial and antiviral activities, among other applications [15-17]. Preparation of 4-anisaldehyde and cinnamaldehyde glucosamine imines and their acetylated derivatives is usually used as a convenient strategy for selective protecting of the amino group of the aminosugar $[11,18,19]$.

Recent studies have shown that Schiff bases derived from glucosamine have antifungal [20] and antibacterial activity [21]. On the other hand, aldehydes present in essential oils may also have action against different microorganisms. Cinnamaldehyde, the main component of Cinnamomum zeylanicum essential oil, specie of Lauraceae family, has several activities such as antioxidant, antibacterial, and antifungal [22]. 

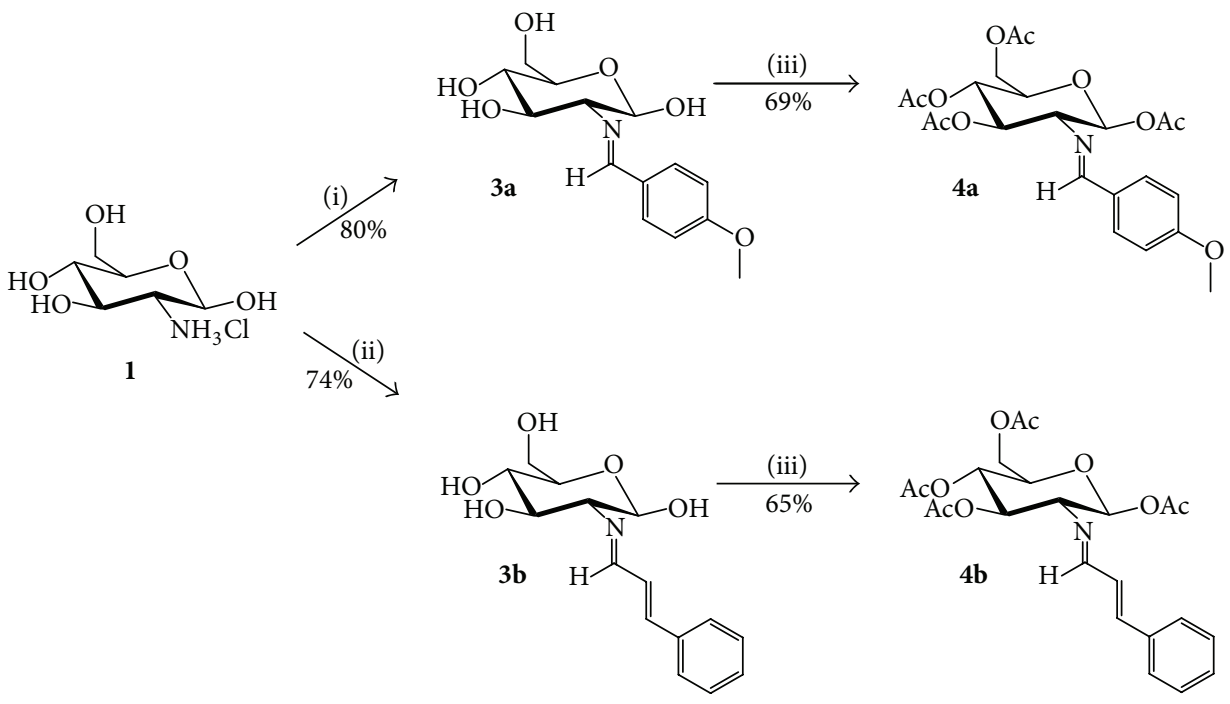

Scheme 1: (i) $1 \mathrm{~N} \mathrm{NaOH}$, anisaldehyde; (ii) $1 \mathrm{~N} \mathrm{NaOH}$, cinnamaldehyde; (iii) acetic anhydride, pyridine.<smiles>COc1ccc(/C=N/CCOC(C)=O)cc1</smiles>

Scheme 2: (i) Anisaldehyde; (ii) cinnamaldehyde; (iii) acetic anhydride, pyridine.

This field has been explored by our research group and in this context, we report herein the synthesis of Schiff bases 3-6 derived from D-glucosamine 1 or 2-aminoethanol 2 and aldehydes in order to evaluate the importance of the presence of carbohydrate moiety for antimicrobial activity.

\section{Results and Discussion}

The synthesis of compounds 3-6 is shown in Schemes 1 and 2. The Schiff bases are readily prepared from $\mathrm{D}$-glucosamine and 2-aminoethanol in one or two straightforward steps.

D-Glucosamine was first converted into the imines 3a or $\mathbf{3 b}$ by treatment with different aldehydes. The resultant imines were acetylated with acetic anhydride and pyridine to the tetra-acetylated glucosamine derivatives $\mathbf{4 a}$ and $\mathbf{4 b}$ (Scheme 1).

To evaluate the importance of the presence of $\mathrm{D}$ glucosamine moiety for antimicrobial activity of the compounds obtained, we plan the synthesis of compounds with similar physical chemistry characteristics, but with simpler structures, without the aminosugar unit. The imines $\mathbf{5}$ and 6 were prepared, by 2 -aminoethanol and the respective aldehyde condensation reaction, followed by acetylation of the hydroxyl group of aminoethanol (Scheme 2). The first step was carried out without the use of solvents, and the expected products were obtained quantitatively. Then we proceeded to the acetylation of 2-(arylidene-amino)ethanol $\mathbf{5}$ hydroxy group with acetic anhydride and pyridine. The yields of these reactions were very good (90 and 93\%). All products were characterized by ${ }^{1} \mathrm{H}$ and ${ }^{13} \mathrm{C}$ NMR.

The compounds 3-6 were evaluated for their efficacy as antibacterial and antifungal agents by disk diffusion method [23-25] against various microbial strains. The in vitro antibacterial activity of the synthesized compounds 3-6 was studied against the following bacterial strains of Grampositive organisms: Staphylococcus aureus (ATCC 25923), Listeria monocytogenes (ATCC 7644), and Enterococcus faecalis (ATCC 29212), and Gram-negative organisms: Escherichia coli (ATCC 25922), Pseudomonas aeruginosa (ATCC 27853), Salmonella choleraesuis (ATCC 10708), and Klebsiella pneumoniae (ATCC 700603), by agar disk diffusion method. We also tested the antifungal activity of compounds 3-6 in Candida albicans (ATCC 90028). Imipenem and Sulfazotrin were used as standard drugs. 
TABLE 1: Antibacterial activity of compounds 3-6, by disk diffusion method ${ }^{\mathrm{a}}$.

\begin{tabular}{|c|c|c|c|c|c|c|c|c|c|}
\hline Entry & Compound & E. coli & L. monocytogenes & P. aeruginosa & S. choleraesuis & K. pneumoniae & E. faecalis & S. aureus & C. albicans \\
\hline 1 & $3 \mathbf{a}$ & - & 8.6 & - & 7.6 & - & 9.3 & 8.3 & 7.3 \\
\hline 2 & $3 b$ & - & 19 & 7 & 7.6 & 7 & 14.3 & 7.6 & 9.3 \\
\hline 3 & $4 a$ & - & - & - & 7 & - & 8.3 & 7.6 & 7 \\
\hline 4 & $4 b$ & 7 & - & - & - & - & - & 7.3 & - \\
\hline 5 & $5 a$ & - & $\mathrm{N}$ & $\mathrm{N}$ & $\mathrm{N}$ & - & - & - & - \\
\hline 6 & $5 b$ & - & $\mathrm{N}$ & $\mathrm{N}$ & $\mathrm{N}$ & - & - & - & - \\
\hline 7 & $6 a$ & - & $\mathrm{N}$ & $\mathrm{N}$ & $\mathrm{N}$ & - & - & - & - \\
\hline 8 & $6 b$ & - & $\mathrm{N}$ & $\mathrm{N}$ & $\mathrm{N}$ & - & - & - & - \\
\hline 9 & Imipenem & 20 & 13 & - & 20 & 17 & 21 & 15.6 & 21 \\
\hline 10 & Sulfazotrin & 23 & 10.3 & - & 29.6 & 16 & 24 & 20 & 13 \\
\hline
\end{tabular}

a Zone of inhibition in $\mathrm{mm}$ (mean).

TABLE 2: Antibacterial activity of compounds 3-4, by microdilution method ${ }^{\mathrm{a}}$.

\begin{tabular}{|c|c|c|c|c|c|c|c|c|c|}
\hline Entry & Compound & E. coli & L. monocytogenes & $P$. aeruginosa & S. choleraesuis & K. pneumoniae & E. faecalis & S. aureus & C. albicans \\
\hline 1 & $3 a$ & & 1.25 & & 1.25 & & 2.5 & 2.5 & 1.25 \\
\hline 2 & $3 b$ & 1.25 & 0.078 & 1.25 & 5 & & 2.5 & 2.5 & 5 \\
\hline 3 & $4 a$ & & & & 5 & & 0.625 & 1.25 & 1.25 \\
\hline 4 & $4 b$ & 1.25 & & & & & & 2.5 & \\
\hline
\end{tabular}

${ }^{\mathrm{a}}$ Minimal inhibitory concentration (MIC) in $\mu \mathrm{g} / \mu \mathrm{L}$ (mean).

From the results shown in Table 1 it can be interpreted that the compounds 3-4 (entries 1-4)are active against Gram-positive, Gram-negative bacteria and fungi strains. It was observed that antibacterial activity of the compounds tested varied significantly depending on the bacteria studied, the highest sensitivity being against Gram-positive compared to Gram-negative strains. Another factor considered was the chemical structure of compounds. Comparing the compounds $\mathbf{3} \mathbf{a}$ and $\mathbf{3} \mathbf{b}$ in the deacetylated form with the acetylated compounds $\mathbf{4 a}$ and $\mathbf{4} \mathbf{b}$ it was verified that the compounds that showed greater antimicrobial activity were the deacetylated compounds. The compound with more activity was $\mathbf{3 b}$, prepared by reaction of $\mathrm{D}$-glucosamine with cinnamaldehyde. Apparently the presence of glucosamine moiety contributes significantly to antimicrobial activity. For compounds $\mathbf{5 a}, \mathbf{5 b}, \mathbf{6 a}$, and $\mathbf{6 b}$, derived from 2 -aminoethanol, it was observed that these compounds showed no activity against the microorganisms evaluated (Table 1, entries 58). A possible explanation for the observed difference in activity between glucosamine derived Schiff bases and those derived from ethanol amine may stem from different rates of hydrolysis for the respective Schiff base.

When the results are compared with standard drugs Imipenem and Sulfazotrin (Table 1, entries 9-10), it was observed that only compound $\mathbf{3 b}$ presented the best activity against Listeria monocytogenes and Pseudomonas aeruginosa.

From the results of disk diffusion method, substances that presented inhibition zone (3a, 3b, $\mathbf{4 a}$, and $\mathbf{4 b}$ ) were studied to determine the minimal inhibitory concentration (MIC) by microdilution method. The results are shown in Table 2. These results confirm that the deacetylated compounds $\mathbf{3 a}$ and $\mathbf{3 b}$ are more active than acetylated derivatives. We also observed the greatest activity against Gram-positive bacteria compared to Gram-negative strains.

The last decade has witnessed a mass downsizing in pharmaceutical antibiotic drug discovery initiatives. Grampositive infections are associated with high rates of morbidity and mortality. Indeed, reports estimate that in 2005 the Gram-positive cocci methicillin resistant $S$. aureus caused more US deaths than HIV/AIDS [26, 27].

The growing spread of multidrug-resistant bacteria, as exemplified by carbapenem-resistant Enterobacteriaceae carrying metallo- $\beta$-lactamase-1 (NDM-1, an enzyme that confers resistance to a broad range of $\beta$-lactam antibiotics), highlights the urgency to find new antimicrobial compounds [28].

When taken together, our results illustrate for the first time that antimicrobial effect of D-glucosamine derivatives is due to the presence of sugar moiety and these compounds can serve as a basis for the development of new antimicrobial agent, but more studies are necessary.

\section{Material and Methods}

All reagents and solvents used were of analytical grade. The ${ }^{1} \mathrm{H}$ NMR $(200$ e $400 \mathrm{MHz})$ and ${ }^{13} \mathrm{C}$ NMR $(50$ e $100 \mathrm{MHz}$ ) spectra were obtained from Bruker DPX200 and DPX400 spectrometers using tetramethylsilane as internal standard.

3.1. Synthesis of 2-Arylidene-2-deoxy- $\beta$-D-glucopyranose 3 (General Procedure). In a $25 \mathrm{~mL}$ round-bottomed flask were added D-glucosamine hydrochloride 1 (1.00 g; $4.6 \mathrm{mmol}), 1 \mathrm{~N}$ $\mathrm{NaOH}(4.6 \mathrm{~mL})$ and the correspondent aldehyde $(4.6 \mathrm{mmol})$. 
The solution was stirred until a solid appeared (10-30 min) and then was maintained in the refrigerator for a few hours. The solid was filtered and washed with cold water and a solution of methanol/ether $(1: 1)$. The product was obtained pure enough.

3.2. 2-(4-Methoxybenzylidene)-2-deoxy- $\beta$-D-glucopyranose 3a. Yield: $80 \%$. ${ }^{1} \mathrm{H}$ NMR (DMSO-d $\mathrm{d}_{6}, 200 \mathrm{MHz}$ ): $\delta=8.12$ $(\mathrm{s}, 1 \mathrm{H}) ; 7.68(\mathrm{~d}, J=8.5 \mathrm{~Hz}, 2 \mathrm{H}) ; 6.98(\mathrm{~d}, 8.5 \mathrm{~Hz}, 2 \mathrm{H}) ; 5.01$ $(\mathrm{d}, J=2.5 \mathrm{~Hz}, 1 \mathrm{H}) ; 3.78(\mathrm{~s}, 3 \mathrm{H}) ; 3.6-3.1(\mathrm{~m}, 10 \mathrm{H}) .{ }^{13} \mathrm{C} \mathrm{NMR}$ (DMSO-d $\left.{ }_{6}, 50 \mathrm{MHz}\right): \delta=161.28,161.03,131.81,129.61,129.05$, $114.50,113.87,95.61,78.09,76.80,74.54,70.34,67.01,61.22$, 55.26 .

3.3. 2-((E)-3-Phenylallylidene)-2-deoxy- $\beta$-D-glucopyranose 3b. Yield: $74 \% .{ }^{1} \mathrm{H}$ NMR (DMSO-d $\left.6,200 \mathrm{MHz}\right): \delta=7.94$ $(\mathrm{d}, J=8.6 \mathrm{~Hz}, 1 \mathrm{H}) ; 7.63-7.56(\mathrm{~m}, 2 \mathrm{H}) ; 7.45-7.30(\mathrm{~m}, 3 \mathrm{H}) ; 7.12$ $(\mathrm{d}, J=16 \mathrm{~Hz}, 1 \mathrm{H}) ; 6.90(\mathrm{dd}, J=16.0,8.6 \mathrm{~Hz}, 1 \mathrm{H}) ; 5.02-4.97$ $(\mathrm{m}, 1 \mathrm{H}) ; 3.78-3.10(\mathrm{~m}, 9 \mathrm{H}) ; 2.72(\mathrm{dd}, J=8.6,8.2 \mathrm{~Hz}, 1 \mathrm{H}) .{ }^{13} \mathrm{C}$ NMR (DMSO-d 6 , $50 \mathrm{MHz}): \delta=163.86,141.26,135.88,129.20$, $129.02,128.47,127.33,95.72,78.43,77.03,74.71,70.42,67.19$, 61.39 .

3.4. Synthesis of 1,3,4,6-Tetra-O-acetyl-2-arylidene-2-deoxy- $\beta$ D-glucopyranose 4 (General Procedure). In a $25 \mathrm{~mL}$ roundbottomed flask, in an ice bath, was prepared a solution of pyridine $(6 \mathrm{~mL})$ and acetic anhydride. And to this solution was added the imine $3(3 \mathrm{mmol})$. The mixture was allowed to stir for $5 \mathrm{~min}$ at $0^{\circ} \mathrm{C}$ and then the reaction was stirred at room temperature for $24 \mathrm{~h}$. After completion of the reaction, the reaction mixture was poured on cold water $(10 \mathrm{~mL})$ and then was maintained in the refrigerator for a few hours. The solid was filtered and washed with cold water to remove pyridine excess.

3.5. 1,3,4,6-Tetra-O-acetyl-2-(4-methoxybenzylidene)-2-deox$y$ - $\beta$-D-glucopyranose 4a. Yield: $69 \%$. ${ }^{1} \mathrm{H} \mathrm{NMR}\left(\mathrm{CDCl}_{3}\right.$; $400 \mathrm{MHz}): \delta=8.16(\mathrm{~s}, 1 \mathrm{H}) ; 7.64(\mathrm{~d}, J=8.7 \mathrm{~Hz}, 2 \mathrm{H}) ; 6.91(\mathrm{~d}$, $J=8.7 \mathrm{~Hz}, 2 \mathrm{H}) ; 5.94(\mathrm{~d}, J=8.2 \mathrm{~Hz}, 2 \mathrm{H}) ; 5.42(\mathrm{t}, J=9.6 \mathrm{~Hz}$, $1 \mathrm{H}) ; 5.12(\mathrm{t}, J=9.6 \mathrm{~Hz}, 1 \mathrm{H}) ; 4.35(\mathrm{dd}, J=12.3,4.7 \mathrm{~Hz} 1 \mathrm{H}) ; 4.14$ (dd, $J=12.3,1.9 \mathrm{~Hz} 1 \mathrm{H}) ; 3.99-3.94(\mathrm{~m}, 1 \mathrm{H}) ; 3.83$ (s, 3H); 3.47$3.41(\mathrm{~m}, 1 \mathrm{H}) ; 2.08(\mathrm{~s}, 3 \mathrm{H}) ; 2.02(\mathrm{~s}, 3 \mathrm{H}) ; 2.00(\mathrm{~s}, 3 \mathrm{H}) ; 1.87(\mathrm{~s}$, $3 \mathrm{H}) .{ }^{13} \mathrm{C} \mathrm{NMR}\left(\mathrm{CDCl}_{3}, 100 \mathrm{MHz}\right): \delta=170.38 ; 169.66 ; 169.27$; $168.48 ; 164.11 ; 162.37 ; 130.14 ; 128.47 ; 114.10 ; 93.25 ; 73.38 ; 72.98$; $72.87 ; 68.37 ; 61.97 ; 55.30 ; 20.56 ; 20.52 ; 20.47 ; 20.31$.

3.6. 1,3,4,6-Tetra-O-acetyl-2-((E)-3-phenylallylidene)-2-deox$y$ - $\beta$-D-Glucopyranose $4 \boldsymbol{b}$. Yield: $65 \% .{ }^{1} \mathrm{H} \mathrm{NMR}\left(\mathrm{CDCl}_{3}\right.$, $200 \mathrm{MHz}): \delta=8.00(\mathrm{~d}, J=8.4 \mathrm{~Hz}, 1 \mathrm{H}) ; 7.61-7.27(\mathrm{~m}, 5 \mathrm{H}) ; 7.04$ $(\mathrm{d}, J=16.0 \mathrm{~Hz}, 1 \mathrm{H}) ; 6.86(\mathrm{dd}, J=16.0,8.4 \mathrm{~Hz}, 1 \mathrm{H}) ; 5.90(\mathrm{~d}$, $J=8.3,1 \mathrm{H}) ; 5.39(\mathrm{t}, J=9.6,1 \mathrm{H}) ; 5.13(\mathrm{t}, J=9.6,1 \mathrm{H}) ; 4.38$ $(\mathrm{dd}, J=12.5,4.4 \mathrm{~Hz}, 1 \mathrm{H}) ; 4.12(\mathrm{dd}, J=12.5,2.0 \mathrm{~Hz}, 1 \mathrm{H}) ; 3.97$ (ddd, $J=9.6,4.4,2.0 \mathrm{~Hz}, 1 \mathrm{H}) ; 3.39(\mathrm{dd}, J=9.6,8.3 \mathrm{~Hz}, 1 \mathrm{H})$; $2.10(\mathrm{~s}, 3 \mathrm{H}) ; 2.07(\mathrm{~s}, 3 \mathrm{H}) ; 2.04(\mathrm{~s}, 3 \mathrm{H}) ; 1.96(\mathrm{~s}, 3 \mathrm{H}) .{ }^{13} \mathrm{C} \mathrm{NMR}$ $\left(\mathrm{CDCl}_{3}, 50 \mathrm{MHz}\right): \delta=170.63 ; 169.85 ; 169.51 ; 168.63 ; 166.74$; $143.92 ; 135.07 ; 129.76 ; 128.90 ; 127.47 ; 127.28 ; 93.04 ; 73.18 ; 72.96$; $72.73 ; 67.99 ; 61.77 ; 20.78 ; 20.72 ; 20.64 ; 20.52$.
3.7. Synthesis of 2-(Arylidene-amino)ethanol 5 (General Procedure). In a $25 \mathrm{~mL}$ round-bottomed flask were added 2aminoethanol 2 (3.05 g; $50 \mathrm{mmol})$ and the correspondent aldehyde $(50 \mathrm{mmol})$ under strong stirring. After a few seconds there was a strong liberation of heat, with water formation. The mixture was stirred for $15 \mathrm{~min}$ and then evaporated in vacuum to eliminate water and unreacted reagents. The product was used without purification.

3.8. (E)-2-((4-Methoxybenzylidene)amino)ethanol 5a. Yield: quant. ${ }^{1} \mathrm{H} \mathrm{NMR}\left(\mathrm{CDCl}_{3} ; 400 \mathrm{MHz}\right): \delta=9.16(\mathrm{~s}, 1 \mathrm{H}) ; 7.61(\mathrm{~d}$, $J=8.8 \mathrm{~Hz}, 2 \mathrm{H}) ; 6.88(\mathrm{~d}, J=8,8 \mathrm{~Hz}, 2 \mathrm{H}) ; 3.87(\mathrm{t}, J=4,6 \mathrm{~Hz}$, $2 \mathrm{H}) ; 3.81(\mathrm{~s}, 3 \mathrm{H}) ; 3.67(\mathrm{t}, J=4,6 \mathrm{~Hz}, 2 \mathrm{H}) ; 3.46(\mathrm{~s}, 1 \mathrm{H}) .{ }^{13} \mathrm{C}$ $\mathrm{NMR}\left(\mathrm{CDCl}_{3} ; 100 \mathrm{MHz}\right): \delta=162.3 ; 161.7 ; 129.7 ; 128.8 ; 113.9$; $63.1 ; 62.2 ; 55.2$.

3.9. 2-((E)-((E)-3-Phenylallylidene)amino)ethanol 5b. Yield: quant. ${ }^{1} \mathrm{H}$ NMR (DMSO-d $\left.{ }_{6} ; 400 \mathrm{MHz}\right): \delta=8.06(\mathrm{~d}, J=$ $4.3 \mathrm{~Hz}, 1 \mathrm{H}) ; 7.6-7.3(\mathrm{~m}, 5 \mathrm{H}) ; 7.08(\mathrm{~d}, J=8 \mathrm{~Hz}, 1 \mathrm{H}) ; 6.89$ (dd, $J$ $=8.0,4.3 \mathrm{~Hz}, 1 \mathrm{H}) ; 3.63(\mathrm{t}, J=3 \mathrm{~Hz}, 2 \mathrm{H}) ; 3.54(\mathrm{t}, J=3 \mathrm{~Hz}, 2 \mathrm{H})$; $3.41(\mathrm{~s}, 1 \mathrm{H}) .{ }^{13} \mathrm{C} \mathrm{NMR}\left(\mathrm{DMSO}-\mathrm{d}_{6} ; 100 \mathrm{MHz}\right): \delta=163.0 ; 140.7$; $135.5 ; 128.8 ; 128.6 ; 128.0 ; 126.9 ; 63.2 ; 60.7$.

3.10. Synthesis of 2-(Arylidene-amino)ethyl Acetate 6 (General Procedure). In a $25 \mathrm{~mL}$ round-bottomed flask, in an ice bath, was prepared a solution of pyridine $(6 \mathrm{~mL})$ and acetic anhydride. And to this solution was added the imine $\mathbf{5}$ $(10 \mathrm{mmol})$. The mixture was allowed to stir for $5 \mathrm{~min}$ at $0^{\circ} \mathrm{C}$ and then the reaction was stirred at room temperature for $24 \mathrm{~h}$. After completion of the reaction, the reaction mixture was treated with saturated aqueous ammonium chloride solution and the whole mixture was extracted 3 times with $\mathrm{CH}_{2} \mathrm{Cl}_{2}$ and the combined organic fractions were collected, dried over $\mathrm{MgSO}_{4}$, and filtered and the solvent was then removed in vacuum. The crude mixture was purified by column chromatography on silica gel eluting with hexane ethyl acetate $(9: 1)$ and then with ethyl acetate.

3.11. (E)-2-((4-Methoxybenzylidene)amino)ethyl Acetate $\mathbf{6} \boldsymbol{a}$. Yield: $90 \% .{ }^{1} \mathrm{H}$ NMR $\left(\mathrm{CDCl}_{3} ; 200 \mathrm{MHz}\right): \delta=7.36-7.25(\mathrm{~m}$, $3 \mathrm{H})$; 6.95-6.85 (m, 2H); 4.17-3.90 (m, 4H); 3.83 (s, 3H); 1.84 $(\mathrm{s}, 3 \mathrm{H}) .{ }^{13} \mathrm{C} \mathrm{NMR}\left(\mathrm{CDCl}_{3} ; 50 \mathrm{MHz}\right): \delta=168.080,160.346$, $159.696,130.241,127.959,114.157,65.508,64.716,55.245,22.731$.

3.12. 2-((E)-((E)-3-Phenylallylidene)amino)ethyl Acetate $\mathbf{6} \boldsymbol{b}$. Yield: $93 \%$. ${ }^{1} \mathrm{H}$ NMR $\left(\mathrm{CDCl}_{3} ; 200 \mathrm{MHz}\right): \delta=7.50-7.20(\mathrm{~m}$, $7 \mathrm{H}) ; 6.71$ (dd, $J=15.6,10.0 \mathrm{~Hz}, 1 \mathrm{H}) ; 4.24-3.48$ (m, 4H); 2.08 $(\mathrm{s}, 3 \mathrm{H}) .{ }^{13} \mathrm{C} \mathrm{NMR}\left(\mathrm{CDCl}_{3} ; 50 \mathrm{MHz}\right): \delta=170.976,167.772$, $134.484,132.266,128.666,128.406,127.937,126.835$, 65.717, $64.834,22.615$.

\section{Conclusion}

In summary, we presented in this report a simple and efficient approach for the preparation of sugar derived Schiff bases. The synthesized D-glucosamine derivatives were shown to possess biological activity when evaluated for antimicrobial 
activity against Gram-positive and Gram-negative bacterial and fungi strains.

\section{Conflict of Interests}

The authors declare that there is no conflict of interests regarding the publication of this paper.

\section{Acknowledgments}

The authors wish to thank FAPERGS, CAPES, and UNIFRA for financial support of their research.

\section{References}

[1] V. F. Ferreira, D. R. da Rocha, and F. De Carvalho Da Silva, "Potentiality and opportunity in chemistry of sucrose and other sugars," Quimica Nova, vol. 32, no. 3, pp. 623-638, 2009.

[2] R. V. Stick, Carbohydrates: The Sweet Molecules of Life, Academic Press, 2001.

[3] M. Diéguez, O. Pàmies, A. Ruiz, Y. Díaz, S. Castillón, and C. Claver, "Carbohydrate derivative ligands in asymmetric catalysis," Coordination Chemistry Reviews, vol. 248, pp. 21652192, 2004.

[4] M. Diéguez, O. Pàmies, and C. Claver, "Ligands derived from carbohydrates for asymmetric catalysis," Chemical Reviews, vol. 104, no. 6, pp. 3189-3216, 2004.

[5] S. Woodward, M. Diéguez, and O. Pàmies, "Use of sugar-based ligands in selective catalysis: recent developments," Coordination Chemistry Reviews, vol. 254, pp. 2007-2030, 2010.

[6] M. Diéguez, C. Claver, and O. Pàmies, "Recent progress in asymmetric catalysis using chiral carbohydrate-based ligands," European Journal of Organic Chemistry, vol. 2007, no. 28, pp. 4621-4634, 2007.

[7] M. M. K. Boysen, "Carbohydrates as synthetic tools in organic chemistry," Chemistry, vol. 13, no. 31, pp. 8648-8659, 2007.

[8] H. R. Appelt, J. B. Limberger, M. Weber et al., "Carbohydrates in asymmetric synthesis: enantioselective allylation of aldehydes," Tetrahedron Letters, vol. 49, no. 33, pp. 4956-4957, 2008.

[9] C. M. Nogueira, B. R. Parmanhan, P. P. Farias, and A. G. Corrêa, "A importância crescente dos carboidratos em química medicinal," Revista Virtual de Química, vol. 1, no. 2, p. 149, 2009.

[10] C.-H. Wong, Ed., Carbohydrate-Based Drug Discovery, WileyVCH, Weinheim, Germany, 2003.

[11] M. Bergmann and L. Zervas, "Synthesen mit glucosamin," Berichte der Deutschen Chemischen Gesellschaft, vol. 64, no. 5, pp. 975-980, 1931.

[12] Z. E. Jolles and W. T. Morgan, "The isolation of small quantities of glucosamine and chondrosamine," Biochemical Journal, vol. 34, no. 8-9, pp. 1183-1190, 1940.

[13] A. N. Bedekar, A. N. Naik, and A. C. Pise, "Schiff base derivatives of 2-amino-2-deoxy-1,3,4,6-tetra-O-acetyl- $\beta$-Dglucopyranose," Asian Journal of Chemistry, vol. 21, no. 9, pp. 6661-6666, 2009.

[14] E. M. S. Pérez, M. Ávalos, R. Babiano et al., "Schiff bases from d-glucosamine and aliphatic ketones," Carbohydrate Research, vol. 345, pp. 23-32, 2010.

[15] J. Costamagna, L. E. Lillo, B. Matsuhiro, M. D. Noseda, and M. Villagrán, "Ni(II) complexes with Schiff bases derived from amino sugars," Carbohydrate Research, vol. 338, no. 15, pp. 1535$1542,2003$.

[16] J. Costamagna, N. P. Barroso, B. Matsuhiro, and M. Villagrán, "Copper(II) complexes with aminosugar derived Schiff bases as ligands," Inorganica Chimica Acta, vol. 273, no. 1-2, pp. 191-195, 1998.

[17] S. Kumar, D. N. Dhar, and P. N. Saxena, "Applications of metal complexes of Schiff bases-a review," Journal of Scientific and Industrial Research, vol. 68, pp. 181-187, 2009.

[18] G. Chauvière, B. Bouteille, B. Enanga et al., "Synthesis and biological activity of nitro heterocycles analogous to megazol, a trypanocidal lead," Journal of Medicinal Chemistry, vol. 46, pp. 427-440, 2003.

[19] M. Ávalos, R. Babiano, P. Cintas et al., "Synthesis of sugar isocyanates and their application to the formation of ureidolinked disaccharides," European Journal of Organic Chemistry, vol. 3, pp. 657-671, 2006.

[20] Y. Xue-Qiong, H. Jian, Y. Chang-Jiang, L. Fang, and L. Qiang, "Synthesis and antifungal activity of D-glucosamine Schiff base," Chemical Reagents, vol. 32, no. 11, pp. 961-964, 2010.

[21] L. Shurong, J. Shuxing, X. Yang, and L. Pu, "Detection of antibacterial activity of some new Schiffbase derivative," Journal of Zhengzhou University Medical Sciences, no. 4, pp. 787-789, 2008.

[22] H. B. Singh, M. Srivastava, A. B. Singh, and A. K. Srivastava, "Cinnamon bark oil, a potent fungitoxicant against fungi causing respiratory tract mycoses," Allergy, vol. 50, no. 12, pp. 995-999, 1995.

[23] E. Margery Linday, Practical Introduction to Microbiology, E \& FN Spon, London, UK, 1962.

[24] C. Perez, M. Paul, and P. Bazerque, "An antibiotic assay by the agar well-diffusion method," Acta Biologiae et Medicine Experimentalis, vol. 15, pp. 113-115, 1990.

[25] D. Kalemba and A. Kunicka, "Antibacterial and antifungal properties of essential oils," Current Medicinal Chemistry, vol. 10, no. 10, pp. 813-829, 2003.

[26] E. A. Bancroft, "Antimicrobial resistance: it's not just for hospitals," The Journal of the American Medical Association, vol. 298, no. 15, pp. 1803-1804, 2007.

[27] R. M. Klevens, M. A. Morrison, J. Nadle et al., "Invasive methicillin-resistant Staphylococcus aureus infections in the United States," The Journal of the American Medical Association, vol. 298, no. 15, pp. 1763-1771, 2007.

[28] K. Bush, "Alarming $\beta$-lactamase-mediated resistance in multidrug-resistant Enterobacteriaceae," Current Opinion in Microbiology, vol. 13, no. 5, pp. 558-564, 2010. 

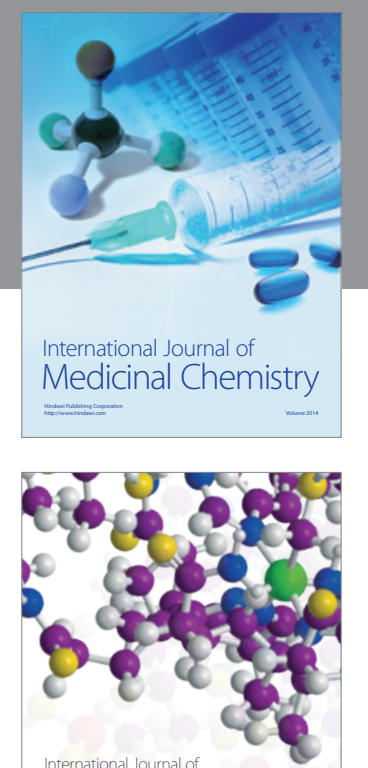

\section{Carbohydrate} Chemistry

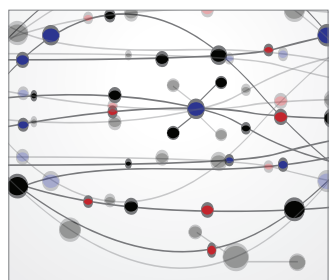

The Scientific World Journal
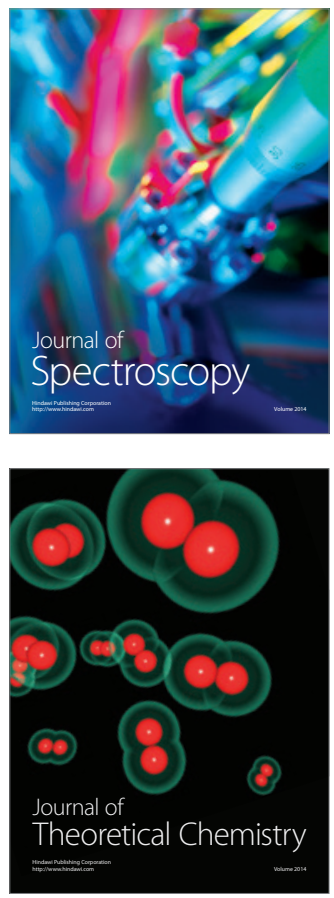
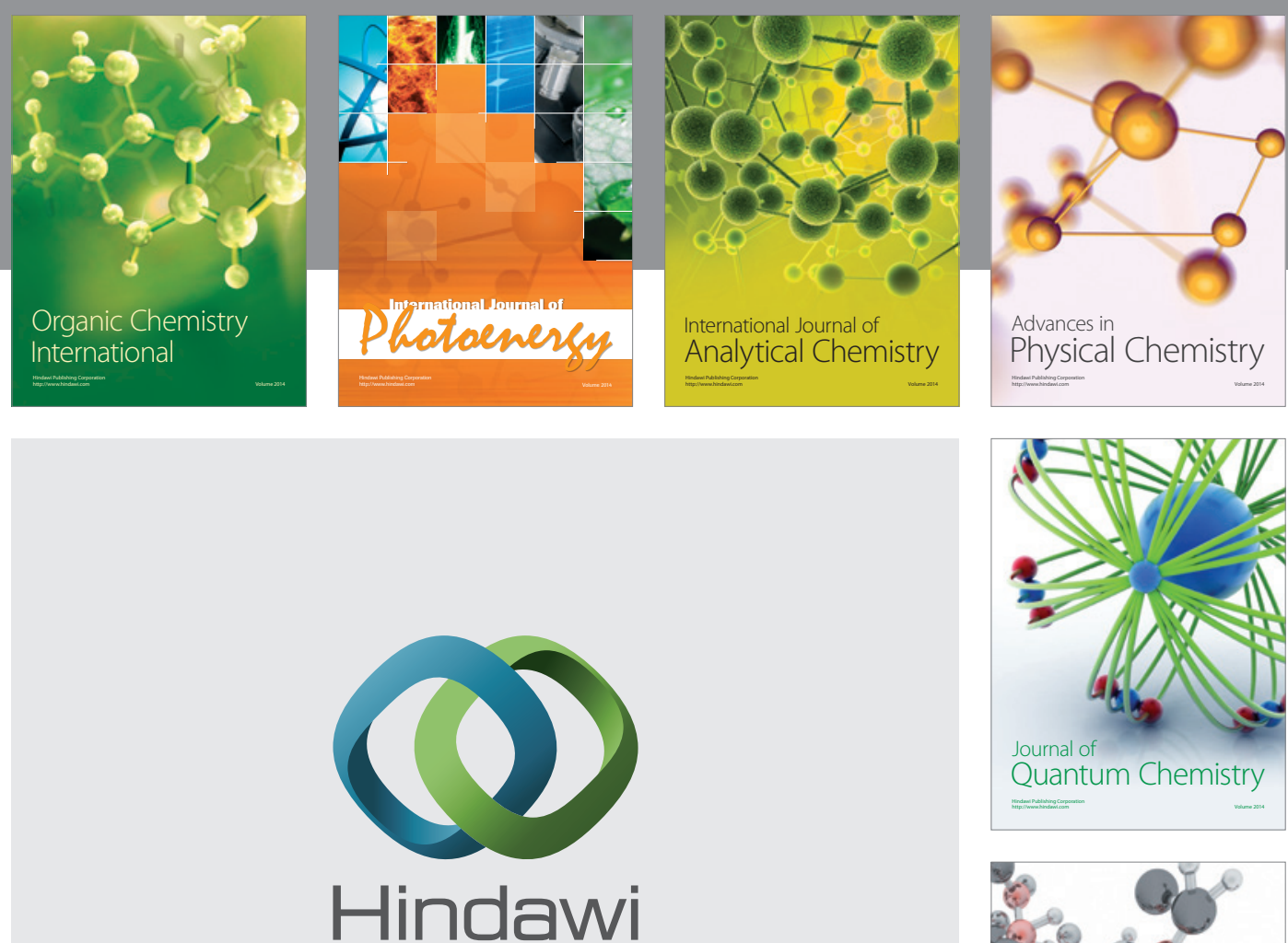

Submit your manuscripts at

http://www.hindawi.com

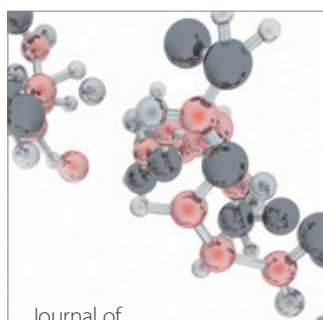

Analytical Methods

in Chemistry

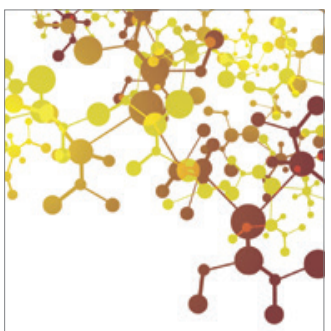

Journal of

Applied Chemistry

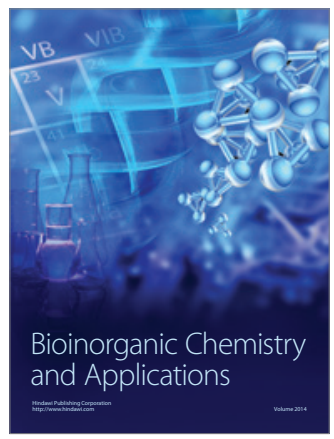

Inorganic Chemistry
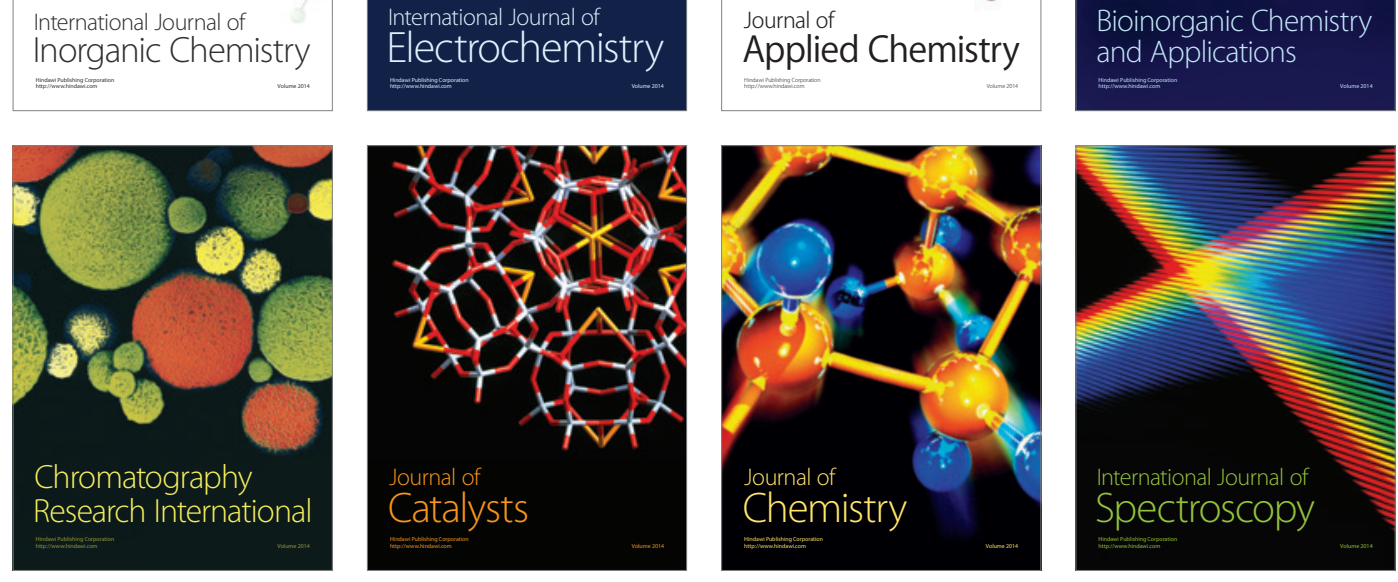